\title{
Kosova Savaşı Gazilerinin Depresyon Anksiyete ve Stres Düzeylerinin Belirlenmesi
}

\author{
Ertan BASHA ${ }^{1}$, Mehmet KAYA ${ }^{2}$
}

\begin{abstract}
Özet: Bu çalışmanın amacı, Kosova'da yaşayan gazilerin depresyon, anksiyete ve stres düzeylerinin: mesleki durum sosyo-ekonomik ve eğitim durumuna göre farklılaşıp farklılaşmadı̆̆ı belirlemektir. Araştırmanın örneklemini Kosova'nın farklı bölgelerinde ikamet etmekte olan gaziler arasından 'Basit Seçkisiz Örnekleme yoluyla seçilen gaziler oluşturmaktadır. Araştırma örneklemi 468'i erkek ve 87 kadın olmak üzere toplam 555 gaziden oluşmaktadır. Çalışmada verilerin toplanması için, '’Depresyon, Anksiyete ve Stres (DASS) Ölçeği’’ kullanılmıştır. Araştırmadan elde edilen verilerin istatistiksel analizi sonucunda; Kosova gazilerinin, mesleki durum, sosyo-ekonomik ve eğitim durumu açısından depresyon, anksiyete ve stres düzeyleri arasında anlamlı farklılıklar olduğu bulunmuştur.
\end{abstract}

Anahtar Sözcükler: Kosova, Depresyon, Anksiyete, Stres, Gazi.

\section{An Evaluation the Level of Depression, Anxiety and Stress the Kosovo War Veterans}

\begin{abstract}
The purpose of this study was to determine the relationship veterans living between depression and anxiety, and professional status, socio-economic status and educational status. Simple random sampling method was used for designating sample. The sample consist of veterans living in different parts of Kosovo. The total number of the sample was 555 including 468 male and 87 female. In the study, the Depression, Anxiety and Stress (DASS) Scale have used to collect data. The data was interpreted evaluating veterans in terms of gender, marital status, get help or not, permanent disability, death of relative, professional status, socio-economic status and educational status. According to the statistical analysis of the data gathered from the participant of the research it has been found that there are significant differences between the levels of depression, anxiety and stress in terms of professional status, social-economic and educational status of Kosovo veterans.
\end{abstract}

Keywords: Kosovo, Depression, Anxiety, Stress, Veteran

${ }^{1}$ Yrd.Doç.Dr., Universiteti AAB, Fakulteti Psikolojise, Orcid Id: https://orcid.org/ 0000-0002-5231-7806

${ }^{2}$ Doç.Dr., Sakarya Üniversitesi Eğitim Fakültesi Eğitim Bilimleri Bölümü Psikoloji Danışma ve Rehberlik Anabilim Dalı, Orcid Id: https://orcid.org/ 0000-0003-2659-3601

Address of correspondence/ Yazışma adresi: Yrd. Doç. Dr. Ertan Basha Unıversiteti ABB. E-mail: ertan.basha@universitetiabb.com

Date of received/ Geliş Tarihi: 23.02.2020, Date of Revision/ Düzeltme Tarihi: 19.04.2020, Date of acceptance/ Kabul Tarihi: 30.04 .2020

Citing/ Referans Gösterimi: Basha, E., Kaya, M. (2020). Kosova Savaşı Gazilerinin Depresyon Anksiyete ve Stres Düzeylerinin Belirlenmesi. Klbrıs Türk Psikiyatri ve Psikoloji Dergisi, 2 (2): 106-13 doi:10.35365/ctjpp.20.02.15

$\mathrm{Bu}$ çalışma ikinci yazarın danışmanlığında birinci yazarın doktora tezinden üretilmiştir. 


\section{Giriş}

Her bireyin genetik özellikleri, fiziksel yapısı, psikolojik geçmişi ve o durum için motivasyonu belirli stresörlerle baş etme düzenekleri farklıdır. Savaşa katılmış gazilerin stres tepkileri ve travma sonrası stres bozukluğu (TSSB) belirtileri, olayın hemen ardından ortaya çıkan tepkiler, uzun dönemli tepkiler ve bu ikisi arasındaki sürede dünyaya ilişkin varsayımlarda ortaya çıkan değişim birçok çalışmaya konu olmuştur. Dekel ve diğ. (2004) tarafından gerçekleştirilen çalışmada gazilerin kontrol grubuna göre, insanların iyiliğine ilişkin daha olumsuz varsayımlara sahip olduğunu; olayın hemen ardından TSSB belirtileri gösterenlerin, göstermeyenlere göre kendileri ve dünyaya ilişkin algılarının daha olumsuz olduğunu; olaydan uzun süre sonra belirti gösterenlerin ise, kronik travma sonrası stres bozukluğu olanlara göre daha olumsuz kendilik değeri algıları olduğunu ortaya koymuştur. Buna benzer bir diğer araştırma da Güneydoğu gazilerinden elde edilen bulgulara göre gazilerde olası TSSB oranı \%29,6 ( $\mathrm{s}=73$ ), TSSB'ye eşlik eden depresyon oran1 ise \%16,6 $(\mathrm{s}=41)$ olarak bulunmuştur (Güloğlu ve Karaırmak, 2013). Vietnam gazilerinde yapılan bir başka çalışmada, olguların \%94'üne en az bir psikiyatrik bozukluk tanısı konmuştur. $\% 65$ ile en s1k görülen bozukluk majör depresyondur. Bunu alkol kötüye kullanımı (\%33) ve sosyal fobi ile yaygın anksiyete bozukluğu (\%25) olarak saptanmışırı (Duran ve Ünsal, 2014: 159) bir diğer araştırmada, depresyon \%26, antisosyal kişilik bozukluğu \%31, distimi \%21, OKB \%10 oranında bulunmuştur Dow ve diğerleri (1996). Hurvatistan'a göç etmiş Bosna'l1 573 kişiyi kapsayan bir çalışmada depresyon \%39.2 oranında gözlenirken TSSB \%26.3 oranında görülmüştür (Mollica ve diğ, 1999). Sally ve diğerlerinin yapmış oldukları çalışmada, elektronik tıbbi kayıtlarla toplamda 1129 gaziyi incelemişlerdir (1032 erkek, 197 kadın), kadın gazilerin MST (military sexual trauma - Askeri cinsel travma) $\% 14$ erkeklerde $\% 1$ ( $\% 14$ vs $\% 1, \mathrm{p}<0,001$ ) daha yüksek depresyon ( $\% 48$ vs $\% 39, \mathrm{p}=0,01)$ ve TSSB ( $\% 21$ vs $\% 33, \mathrm{p}=0,002)$ Yaptıkları klinik çalışmada kadın ve erkelerin almış oldukları almış oldukları puanlar önemli bir cinsiyet farklılığı olmadığını göstermiştir (Sally ve diğ, 2010). İkinci Dünya Savaşı esirleri ile ilgili bir çalışmada yaşam boyu TSSB yaygınlığ $\% 50$ bulunmuştur. Travmadan yaklaşı 50 yıl sonra aynı popülasyonda yapılan değerlendirmede TSSB'nin \%29 oranında halen devam ediyor olması, yaşam boyu TSSB ile birlikte \%71 oranında yaygın anksiyete bozukluğu, $\% 45$ oranında majör depresyon ve $\% 39$ oranında alkol ve madde kötüye kullanımının görülmesi, TSSB ve komorbid durumların zaman içindeki gidişini belirleyen etkenlere dikkati çekmektedir (Kaya, 2000). Türkiye'de terör saldırılarında yapılan çalışmalara bakıldığında, (Eşsizoğlu ve diğ, 2009), 03 Ocak 2008 yılında Diyarbakır'da bir otomobil içerisine konulan patlayıcılarla gerçekleştirilen terör saldırım sonrasında, bu patlamaya görsel ve işitsel olarak tanıklık etmiş kişilerde, 1 . ay sonunda 216 kişinin $\% 12.5$, 3. ay sonunda 146 kişinin \%9.6'sinda TSSB geliştiğini saptamışlardır. Yine Türkiye'de yapılan terör saldırılarıyla ilgili bir çalışmada ise 15 ile 20 Kasım 2003 tarihlerinde İstanbul'un dört ayrı yerine yapılan bombalama eylemlerinden iki ay sonra gerçekleştirilmiştir. Bu çalışmada patlamaların olduğu bölgede bulunan bir okuldaki ergenler arasında TSSB oranının \%5.9 olduğu, patlamalardan sonra karakollara başvuran yetişkinler arasında TSSB oranının ise \%29.9 olduğu belirlenmiştir
(Aker ve diğ, 2008). Tekrarlayan terör saldırılardan etkilenen topluluklarda, yeni bir saldırının gerçekleşebileceği ile ilgili kaygının anlamlı derecede daha yüksek olduğu, bu durumun saldırıdan sonraki erken dönemde gelişen TSSB semptomlarının iyileşmesini olumsuz yönde etkilediği ve bu topluluklarda TSSB yaygınlığının daha yüksek olduğu bildirilmiştir (Shalev ve Freedman 2005). Bu bulgular terör saldirısının kendisinin, tıpkı daha önceden travma öyküsüne sahip olmak gibi, yeni bir terör saldırıdan sonra TSSB gelişimi için bir risk faktörü olabileceğini göstermektedir. ABD'de ve Finlandiya'da bir okulda yapılan çalışmada diğerlerinin vurularak öldürülmesine şahit olan ergenlerin 1 ay sonra ergenlerin \%38'inde ve 4 ay sonra \%19.2' sinde TSSB ortaya çıktığı saptanmıştır (Pynoos ve diğ, 1987). Terör saldırılarının, savaşın ya da doğal afetlerin ortaya çıkması demek insanların ölmesi, yaralanması, sakatlanması, aile fertlerini kaybetmesi, acı çekmesi ve değişik psikolojik sorunlarının meydana gelmesi demektir. Yapılan araştırmalara göre savaş ve doğal afet gibi olağanüstü durumlara bağlı gelişen en yaygın psikolojik bozukluklar şöyle sıralanmadır: Travma Sonrası Stres Bozukluğu, Depresyon, Stres, Anksiyete, Uyum Bozukluğu, Dissosiyatif Amnezi, Dissosiyatif Füg, Dissosiyatif Kimlik Bozukluğu, Depersonalizasyon Bozukluğu, Somatizasyon Bozukluğu, Konversiyon Bozukluğu görülmektedir. $\mathrm{Bu}$ tür bozuklukları destekleyen araştırmalarda aşağıda gösterilmeye çalışılmıştır. Davidson ve arkadaşları (1985) tarafından savaş sonrası savaşı yaşayan bireylerle yapılan araştırmaya göre savaşın TSSB tedavisini karmaşık hale getirdiği ve tedavinin gecikmesine yol açacağını belirtilmiştir. Yapmış oldukları araştırmalarında TSSB'lilerin ailelerinde \%66 oranında psikopatoloji saptamıştır. $\mathrm{Bu}$ oran depresyonlularda \%79, anksiyete bozulduğu olanlarda ise $\% 93$ olarak veri elde edilmiştir. $\mathrm{Bu}$ çalışmaların getirdiği sonuç, TSSB'lilerin stres karşısında bu sendromu oluşturmaya daha eğilimli oldukları saptanmıştır (Davidson ve diğ, 1985). Buna benzer bir diğer araştırmada ise, TSSB nadir bir rahatsızlık değildir kanıtına varmışlardır. Yaşam boyu prevalans \% 1 civarında bulunmuş (genel popülasyonda). Fiziksel bir saldırıyla karşı karşıya kalanlarda bu oran 3,5 savaşta ise \% 20'ye ulaşmaktadır. Bu çalışmaya benzer bazı çalışmalar bu oranların sırasıyla \% 25 ve \% 31 yaşam boyu prevalansı olduğu yönündedir. Örneğin Falkland savaşı sırasında $\% 22$ oranında TSSB görülmüştür (O’Brien ve Hughes, 1991). Örneğin Falkland savaşı sırasında \%22 oranında TSSB görülmüştür (O’Brien ve Hughes, 1991). Travma sonras1 gelişim, bazı araştırmacılara göre yaşanan travmatik olaylardan sonra da ağır stres tepkileri göstermelerinde risk faktörleri oluşabileceğini ortaya çıkartmışlardır. Travma sonrası gelişim, bazı araştırmacılara göre yaşanan travmatik olaylardan sonra da agır stres tepkileri göstermelerinde risk faktörleri oluşabileceğini ortaya çıkartmışlardır. Travma sonrası stres bozukluğu (TSSB) gelişiminde birçok faktörün etkili olduğu bilinmektedir. $\mathrm{Bu}$ tartışmalar özetle iki ana görüş üzerinden şekillenmektedir. Bunlardan biri travma sonucu meydana gelen değişikliklerin TSSB'nun temel sebebi olduğu, diğeri ise bireyde travma öncesinde de var olan yatkınlığın ana belirleyici olduğu şeklindedir. Ancak, stresör temel ortaya çıkarıcı etken olmakla birlikte, aynı travmatik olayı yaşayan herkeste TSSB tablosu oluşmamaktadır. Travma kaynağının hasta için öznel 
anlamının önemi üzerinde giderek fikir birliğine varılmaktadır (Özgen, 1991). Dünyanın birçok bölgesinde savaş sonrası bireylerin psikolojik durumlarının olumsuz etkileyen durumları inceleyen çalışmalar gerçekleştirilmiştir. Kosova'da 1999 yılında yaşanan iç savaş (Kosova bağımsızlık savaşı) savaşa katılan bireylerin UÇK (Kosova bağımsızlık ordusu) gazilerin psikolojik durumlarının incelenmesi üzerine gerçekleştirilen akademik bir çalışma yapılmamıştır. $\mathrm{Bu}$ çalışma Kosova gazilerinin depresyon, aksiyete ve stres düzeylerinin incelenmesi amaciyla gerçekleştirilmiştir.

\section{Yöntem ve Gereç}

$\mathrm{Bu}$ araştırma nicel araştırma türlerinden tarama türünde bir araştırmadır. Cinsiyet, medeni durum, yardım alıp almama, kalıcı sakatlık, yakın kaybı, mesleki durum, sosyo-ekonomik durum ve eğitim düzeyleri ile depresyon, anksiyete ve strese göre farklılaşıp farklılaşmadığını belirlemek amacıyla araştırma verileri toplanmıştır. Tarama modelleri, "geçmişte ya da halen var olan bir durumu var olduğu şekliyle betimlemeyi amaçlayan araştırma yaklaşımlarıdır. Bu modelde önemli olan, var olanı değiştirmeye kalkmadan gözlemleyebilmektir” (Karasar, 1991: 77).

\section{Evren ve Örneklem}

Kosova gazilerinin depresyon, anksiyete ve stres düzeylerinin arasında ilişkiyi incelemek amacıyla yapılan bu çalışmanın evrenini, Kosova'nın çeşitli il ve ilçelerinde ikamet etmekte olan bireyler oluşturmaktadır. Söz konusu il ve ilçeler; Prishtina, Prizren, Gjakova, İpek, Korisha ve Krusha’yı kapsamaktadır.

Araştırmanın örneklemini ise, bu il ve ilçelerde yaşayan 600 gazi oluşturmaktadır. Ölçek ve demografik verilerle ilgili anket formları 600 gaziye ulaştırılmıştır, ancak yanlış veriler işaretleyen gaziler anketler formları çıkarttırıldığında 555 gaziye ait veri analizlerde kullanılmaya uygun olduğu belirlenmiştir. Dolayısıyla araştırma örneklemi 468'i erkek ve 87 kadın olmak üzere toplam 555 gaziden oluşmaktadır.

\section{Kişisel Bilgi Formu}

Gazilerle ilgili birtakım değişkenler hakkında bilgi toplamak amacıyla araştırmacı tarafından geliştirilmiştir.
Kişisel Bilgi Formunda gazilerin cinsiyet, medeni durum, daha önce her hangi bir psikolojik yardım alıp almadıkları, savaşta kalıcı bir sakatlık olup olmadığı, savaşta yakın derecede kaybı var mı yok mu, mesleki durum ve sosyoekonomik düzey bulunmaktadır. Etik kurallar ve gerçekçi cevap alabilmek amacıyla araştırma sırasında gazilere kimlik bilgilerini içeren sorular yöneltilmemiştir.

\section{Depresyon, Anksiyete ve Stres Ölçeği}

Lovibond ve Lovibond (1995a) tarafindan geliştirilen Depression Anxiety Stress Scale (DASS)'da 14'ü depresyon, 14'ü anksiyete ve 14'ü stres boyutlarına ait olmak üzere toplam 42 madde bulunmaktadır. Ölçek 0 bana hiç uygun değil 1 bana biraz uygun, 2 bana genellikle uygun ve 3 bana tamamen uygun, şeklinde 4'lü likert tipi bir derecelendirmeye sahiptir. Depresyon, anksiyete ve stres boyutlarının her birinden alınan puanların yüksek olması, bireyin ilgili probleme sahip olduğunu ortaya koymaktadır. Ters madde bulunmayan ölçeğin toplam puanları her bir alt boyut için 0 ile 42 arasında değişmektedir. Ölçeğin Arnavutça 'ya uyarlanması sürecinde bir dizi geçerlik ve güvenirlik çalışması yapılmıştır. Öncelikle ölçeğin çeviri süreci yapılmıştır. Araştırmada elde edilen bulgular Arnavutça ve İngilizce (orijinal) formlar arasındaki ilgileşim katsayılarının, depresyon için. $85(\mathrm{p}<.01)$, anksiyete için. $81(\mathrm{p}<.01)$, stres için. $80(\mathrm{p}<.01)$ olduğu görülmüştür.

\section{Bulgular}

Kosova'da yaşamına devam eden gazilerin, farklı değişkenler açısından depresyon, anksiyete ve stres düzeylerini belirlemek için yapılan analizler sonucunda elde edilen bulgulara yer verilmiştir. Bulguların sunulmasında araştırma problemi ve alt problemler sırası ile ele alınarak, her bir alt probleme ilişkin verilerin istatistiksel çözümlemeleri doğrultusunda ulaşılan bulgulara yer verilmiştir.

Gazilerin depresyon, anksiyete ve stres düzeylerinin mesleki durumlarına göre değişip değişmediğinin incelenmesi için tek yönlü varyans analizi kullanılmıştır. Elde edilen sonuçlar Tablo 1 ve 2'de gösterilmiştir.

Tablo 1. Mesleki Durum Değişkenine Göre Katılımcıların Depresyon Anksiyete ve Stres Puan Ortalamaları Standart Sapmaları

\begin{tabular}{|c|c|c|c|c|}
\hline Bağımlı Değişken & Mesleki Durum & $\mathrm{N}$ & Ortalama & $\begin{array}{l}\text { Standart Sapma } \\
\text { San }\end{array}$ \\
\hline \multirow[t]{5}{*}{ Depresyon } & Çalışıyor & 317 & 11,77 & 7,53 \\
\hline & Çalışmiyor & 179 & 13,01 & 7,81 \\
\hline & Emekli & 33 & 15,42 & 6,50 \\
\hline & Hiç Çalışmamış & 27 & 11,62 & 7,75 \\
\hline & Toplam & & 1238 & 762 \\
\hline \multirow{6}{*}{ Anksiyete } & Çalıșıyor & 317 & 13,23 & 6,92 \\
\hline & Çalışmıyor & 179 & 13,81 & 6,87 \\
\hline & Emekli & 33 & 17,93 & 5,88 \\
\hline & Hiç Çalışmamış & 27 & 13,40 & 8,50 \\
\hline & Toplam & & & \\
\hline & & 555 & 13,70 & 7,00 \\
\hline \multirow[t]{5}{*}{ Stress } & Çalıșıyor & 317 & 15,59 & 6,85 \\
\hline & Çalışmıyor & 179 & 16,10 & 7,06 \\
\hline & Emekli & 33 & 18,72 & 5,65 \\
\hline & HiçÇalışmamış & 27 & 15,40 & 6,77 \\
\hline & Toplam & 555 & 15,93 & 6,87 \\
\hline
\end{tabular}


Tablo 1'de $(N=555)$ mesleki durumu değişkeni düzeylerine göre katılımcıların depresyon, anksiyete ve stres düzeyleri arasındaki fark incelenmiştir. Yapılan incelemede depresyon düzeylerinin çalışma grubunu oluşturan çalışanlara ait depresyon düzeylerinin ortalamaları $\bar{X}=11,77(S S=7,53)$, anksiyete düzeylerine ait puan ortalamaları $\bar{X}=13,23 \quad(S S=6,92)$, stres düzeylerine ait puan ortalamaları $\bar{X}=15,59 \quad(S S=6,85)$ olarak bulunmuştur. Çalışmayanlara ait depresyon düzeylerinin ortalamaları $\bar{X}=13,01 \quad(S S=7,81)$, anksiyete düzeylerine ait puan ortalamaları $\bar{X}=13,81 \quad(S S=6,87)$, stres düzeylerine ait puan ortalamaları $\bar{X}=16,10$ $(S S=7,06)$ olarak hesaplanmıştır. Emeklilere ait depresyon düzeylerinin ortalamaları $\bar{X}=15,42(S S=6,50)$, anksiyete düzeylerine ait puan ortalamaları $\bar{X}=17,93$ $(S S=5,88)$, stres düzeylerine ait puan ortalamaları $\bar{X}=18,72$ 'dir $(S S=5,65)$. Hiç çalışmamış bireylere ait depresyon düzeylerinin ortalamalar1 ise $\bar{X}=11,62$ $(S S=7,75)$, anksiyete düzeylerine ait puan ortalamaları $\bar{X}=13,40 \quad(S S=8,50), \quad$ stres düzeylerine ait puan ortalamaları $\bar{X}=15,40$ 'dir $(S S=6,77)$. Toplam depresyon düzeylerinin ortalamaları $\bar{X}=12,38(S S=7,62)$, anksiyete düzeylerine ait puan ortalamaları $\bar{X}=13,70(S S=7,00)$, stres düzeylerine ait ortalamaları $\bar{X}=15,93 \quad(S S=6,87)$, olarak bulunmuştur.

Tablo 2. Mesleki Durum Değişkenine Göre Katılımcıların Depresyon, Anksiyete ve Stres Düzeylerine İlişkin Tek Yönlü Varyans Analizi Sonucu

\begin{tabular}{|c|c|c|c|c|c|c|}
\hline & & Kareler Toplamı & $\mathrm{SD}$ & Kareler Ortalaması & $\mathrm{F}$ & $P$ \\
\hline \multirow{3}{*}{ Depresyon } & Gruplar arası & 507,969 & 3 & 169,323 & 2,945 & ,032 \\
\hline & Gruplar İçi & 31739,432 & 552 & 57,499 & & \\
\hline & Toplam & 32247,401 & 555 & & & \\
\hline \multirow[t]{3}{*}{ Anksiyete } & Gruplar arası & 667,497 & 3 & 222,499 & 4,625 & ,003 \\
\hline & Gruplar İçi & 26556,128 & 552 & 48,103 & & \\
\hline & Toplam & 27223,626 & 555 & & & \\
\hline \multirow{3}{*}{ Stres } & Gruplar aras1 & 306,100 & 3 & 102,033 & 2,171 & ,090 \\
\hline & Gruplar İçi & 25937,569 & 552 & 46,988 & & \\
\hline & Toplam & 26243,669 & 555 & & & \\
\hline
\end{tabular}

Tablo 2'de $(N=555)$ mesleki durum düzeyine göre katılımcıların depresyon, anksiyete ve stres düzeyleri arasındaki fark incelenmiştir. Mesleki durum düzeyine göre depresyon, anksiyete ve stres düzeylerinin puan ortalamaları arasında farkın olup olmadığını belirlemek için yapılan tek yönlü varyans analizi sonucunda depresyon düzeyinde $[F(2,945)=, 032 ; p>.05]$ anlaml fark olduğu bulunmuştur, anksiyete düzeyinde $[F(4,625)=, 003 ; \quad p>.05]$ anlaml 1 fark olduğu bulunmuştur, stres düzeyinde $[F(4,625)=, 090 ; p<.05]$ anlamlı bir farkın olmadığ 1 saptanmıştır. Gruplar arasındaki farkı ortaya çıkarmak için yapılan Tukey testi sonuçlarına göre emekli olan gazilerin çalışan gazilere göre depresyon ve anksiyete düzeylerinin daha yüksek olduğu görülmüştür. Ayrica emekli olan gazilerin anksiyete düzeylerinin çalışmayan gazilere göre yine daha yüksek olduğu görülmüştür.

Gazilerin depresyon, anksiyete ve stres düzeylerinin Sosyo-Ekonomik durumlarına göre değişip değişmediğinin incelenmesi için tek yönlü varyans analizi kullanılmıştır. Elde edilen sonuçlar Tablo 3 ve 4'te gösterilmiştir.

Tablo 3. Sosyo-Ekonomik Değişkenine Göre Katılımcıların Depresyon Anksiyete ve Stres Puan Ortalamaları Standart Sapmaları.

\begin{tabular}{|c|c|c|c|c|}
\hline Bağımlı Değişken & Sosyo-Ekonomik & $\mathrm{N}$ & Ortalama & Standart Sapma \\
\hline \multirow{4}{*}{ Depresyon } & Düşük & 103 & 15,02 & 8,12 \\
\hline & Orta & 391 & 11,83 & 7,30 \\
\hline & Yüksek & 62 & 11,41 & 7,87 \\
\hline & Toplam & 555 & 12,38 & 7,62 \\
\hline \multirow{4}{*}{ Anksiyete } & Düşük & 103 & 15,33 & 7,58 \\
\hline & Orta & 391 & 13,45 & 6,84 \\
\hline & Yüksek & 62 & 12,59 & 6,69 \\
\hline & Toplam & 555 & 13,70 & 7,00 \\
\hline \multirow{4}{*}{ Stress } & Düşük & 103 & 17,50 & 8,01 \\
\hline & Orta & 391 & 15,66 & 6,51 \\
\hline & Yüksek & 62 & 15,04 & 6,81 \\
\hline & Toplam & 555 & 15,93 & 6,87 \\
\hline
\end{tabular}


Tablo 3'te $(\mathrm{N}=555)$ Sosyo-ekonomik durum değişkeni düzeylerine göre katılımcıların depresyon, anksiyete ve stres düzeyleri arasındaki fark incelenmiştir. Yapılan incelemede depresyon düzeylerinin sosyo-ekonomik açıdan düşük derecede olan bireylerin ortalamaları $\bar{X}=15,02$ (SS=8,12), orta derece düzeylerine ait puan ortalamaları $\bar{X}=11,83 \quad(\mathrm{SS}=7,30)$, yüksek derecede düzeylerine ait puan ortalamaları $\bar{X}=11,41, \quad(\mathrm{SS}=7,87)$ olarak bulunmuștur. Anksiyete düzeylerinin sosyoekonomik açıdan düşük derecede olan bireylerin ortalamaları $\bar{X}=15,33(\mathrm{SS}=7,58)$, orta derece düzeylerine ait puan ortalamaları $\bar{X}=13,45 \quad(\mathrm{SS}=6,84)$, yüksek derecede düzeylerine ait puan ortalamaları $\bar{X}=12,59$, $(\mathrm{SS}=6,69)$ olarak bulunmuştur. Stres düzeylerinin sosyoekonomik açıdan düşük derecede olan bireylerin ortalamaları $\bar{X}=17,50(\mathrm{SS}=8,01)$, orta derece düzeylerine ait puan ortalamaları $\bar{X}=15,66 \quad(\mathrm{SS}=6,51)$, yüksek derecede düzeylerine ait puan ortalamaları $\bar{X}=15,04$, ( $\mathrm{SS}=6,87)$ olarak bulunmuştur.

Tablo 4. Sosyo-Ekonomik Değişkenine Göre Katılımcıların Depresyon, Anksiyete ve Stres Düzeylerine İlişkin ANOVA Analizi Sonucu

\begin{tabular}{|c|c|c|c|c|c|c|}
\hline & & Kareler Toplamı & $\mathrm{SD}$ & Kareler Ortalaması & $\mathrm{F}$ & $P$ \\
\hline \multirow{3}{*}{ Depresyon } & Gruplar aras1 & 894,543 & 2 & 447,271 & 7,889 & ,000 \\
\hline & Gruplar İçi & 31352,859 & 553 & \multirow{2}{*}{56,696} & & \\
\hline & Toplam & 32247,401 & 555 & & & \\
\hline \multirow{3}{*}{ Anksiyete } & Gruplar aras1 & 667,497 & 3 & 185,528 & 3,842 & ,022 \\
\hline & Gruplar İçi & 2685.0571 & 553 & \multirow{2}{*}{48,554} & & \\
\hline & Toplam & 27223,626 & 555 & & & \\
\hline \multirow{3}{*}{ Stres } & Gruplar aras 1 & 306,100 & 3 & 165,815 & 3,539 &, 030 \\
\hline & Gruplar İçi & 25912,040 & 553 & \multirow{2}{*}{46,857} & & \\
\hline & Toplam & 26243,669 & 555 & & & \\
\hline
\end{tabular}

Gazilerin sosyo-ekonomik durum düzeyine göre katılımcıların depresyon, anksiyete ve stres düzeyleri arasındaki fark incelenmiştir. Sosyo-ekonomik düzeyine göre depresyon, anksiyete ve stres düzeylerinin puan ortalamaları arasında fark olup olmadığını belirlemek için yapılan tek yönlü varyans analizi sonucunda depresyon düzeyinde $[\mathrm{F}(7,889)=, 000 ; \mathrm{p}>.05]$ anlaml fark olduğu bulunmuştur, anksiyete düzeyinde $[\mathrm{F}(3,842)=, 022$; $\mathrm{p}>.05]$ anlamlı fark olduğu bulunmuştur, stres $[\mathrm{F}(7,889)=$ ,030; p> .05] anlamlı fark olduğu bulunmuştur.
Gruplar arasındaki farkı ortaya çıkarmak için yapılan Tukey testi sonuçlarına göre emekli olan gazilerin çalışan gazilere göre depresyon ve anksiyete düzeylerinin daha yüksek olduğu görülmüştür. Ayrıca sosyo-ekonomi durumları düşük olan gazilerin depresyon ve anksiyete düzeylerinin daha yüksek olduğu görülmüştür. Gazilerin depresyon, anksiyete ve stres düzeylerinin eğitim durumlarına göre değişip değişmediğinin incelenmesi için tek yönlü varyans analizi kullanılmıştır. Elde edilen sonuçlar Tablo 5 ve 6'da gösterilmiştir.

Tablo 5. Eğitim Durumu Değişkenine Göre Katılımcıların Depresyon Anksiyete ve Stres Puan Ortalamaları Standart Sapmaları.

\begin{tabular}{|c|c|c|c|c|}
\hline Bağımlı Değişken & Eğitim Durumu & $\mathrm{N}$ & Ortalama & Standart Sapma \\
\hline \multirow{6}{*}{ Depresyon } & İlk Okul & 51 & 18,00 & 7,22 \\
\hline & Ortaokul & 280 & 12,83 & 7,72 \\
\hline & Yüksekokul & 108 & 11,63 & 7,04 \\
\hline & Fakülte & 93 & 9,25 & 6,59 \\
\hline & Yüksek lisans & 24 & 1,058 & 6,53 \\
\hline & Toplam & 555 & 12,38 & 7,62 \\
\hline \multirow{6}{*}{ Anksiyete } & İlk Okul & 51 & 18,54 & 6,35 \\
\hline & Ortaokul & 280 & 13,96 & 7,13 \\
\hline & Yüksekokul & 108 & 12,45 & 6,55 \\
\hline & Fakülte & 93 & 11,59 & 6,19 \\
\hline & Yüksek lisans & 24 & 14,25 & 6,79 \\
\hline & Toplam & 555 & 13,70 & 7,00 \\
\hline \multirow{6}{*}{ Stress } & İlk Okul & 51 & 19,50 & 7,09 \\
\hline & Ortaokul & 280 & 16,08 & 6,82 \\
\hline & Yüksekokul & 108 & 14,66 & 6,32 \\
\hline & Fakülte & 93 & 14,73 & 6,95 \\
\hline & Yüksek lisans & 24 & 16,95 & 6,64 \\
\hline & Toplam & 555 & 15,93 & 6,87 \\
\hline
\end{tabular}


Tablo 5'te $(\mathrm{N}=555)$ eğitim durumu değişkeni düzeylerine göre katılımciların depresyon, anksiyete ve stres düzeyleri fark incelenmiştir. Yapılan incelemede depresyon düzeylerinin eğitim açısından ilkokula ait bireylerin ortalamaları $\bar{X}=18,00 \quad(\mathrm{SS}=7,22)$, ortaokul düzeylerine ait puan ortalamaları $\bar{X}=12,83$ (SS=7,72), yüksekokul düzeylerine ait puan ortalamaları $\bar{X}=11,63$ $(\mathrm{SS}=7,04)$, fakülte düzeylerine ait puan ortalamaları $\bar{X}=9,25$ (SS=6,59), yüksek lisans düzeylerine ait puan ortalamaları $\bar{X}=1,058$ (SS=6,53) olarak hesaplanmıştır. Anksiyete düzeylerinin eğitim açısından ilkokula ait bireylerin ortalamaları $\bar{X}=18,54 \quad(\mathrm{SS}=6,35)$, ortaokul düzeylerine ait puan ortalamaları $\bar{X}=13,96(\mathrm{SS}=7,13)$, yüksekokul düzeylerine ait puan ortalamaları $\bar{X}=12,45$ $(\mathrm{SS}=6,55)$, fakülte düzeylerine ait puan ortalamaları $\bar{X}=11,59$ (SS=6,19), yüksek lisans düzeylerine ait puan ortalamaları $\bar{X}=14,25 \quad(\mathrm{SS}=6,79)$ olarak bulunmuştur. Stres düzeylerinin eğitim açısından ilkokula ait bireylerin ortalamaları $\bar{X}=19,50(\mathrm{SS}=7,09)$, ortaokul düzeylerine ait puan ortalamaları $\bar{X}=16,08 \quad(\mathrm{SS}=6,82)$, yüksekokul düzeylerine ait puan ortalamaları $\bar{X}=14,66 \quad(\mathrm{SS}=6,32)$, fakülte düzeylerine puan ortalamaları $\bar{X}=14,73$ $(\mathrm{SS}=6,95)$, yüksek lisans düzeylerine ait puan ortalamaları $\bar{X}=16,95$ ' dir $(\mathrm{SS}=6,64)$.

Tablo 6. Eğitim Durumu Değişkenine Göre Katılımcıların Depresyon, Anksiyete ve Stres Düzeylerine İlişkin ANOVA Analizi Sonucu

\begin{tabular}{|c|c|c|c|c|c|c|}
\hline & & Kareler Toplamı & SD & Kareler Ortalaması & $\mathrm{F}$ & $p$ \\
\hline \multirow{3}{*}{ Depresyon } & Gruplar arası & 2712,077 & 4 & 678,269 & 12,654 & ,000 \\
\hline & Gruplar İçi & 29534 & 551 & \multirow{2}{*}{53,601} & & \\
\hline & Toplam & 32247,401 & 555 & & & \\
\hline \multirow{3}{*}{ Anksiyete } & Gruplar arası & 1803,689 & 4 & 451,672 & 9,792 & ,000 \\
\hline & Gruplar İçi & 25416,937 & 551 & \multirow{2}{*}{46,129} & & \\
\hline & Toplam & 27223,626 & 555 & & & \\
\hline \multirow{3}{*}{ Stres } & Gruplar aras1 & 991,743 & 4 & 247,936 & 5,410 & ,000 \\
\hline & Gruplar İçi & 25251,926 & 551 & \multirow{2}{*}{45,829} & & \\
\hline & Toplam & 26243,669 & 555 & & & \\
\hline
\end{tabular}

Tablo 6'da Eğitim durum düzeyine göre katılımcıların depresyon, anksiyete ve stres düzeyleri arasındaki ilişkin incelenmiştir. eğitim durumuna göre depresyon, anksiyete ve stres düzeylerinin puan ortalamaları arasında fark olup olmadığını belirlemek için yapılan tek yönlü varyans analizi sonucunda depresyon düzeyinde $[F(12,654)=, 000 ; \quad p>.05]$ anlaml fark olduğu bulunmuştur, anksiyete düzeyinde $[F(9,792)=, 000$; $p>.05]$ anlamlı fark olduğu bulunmuştur, stres $[F(5,410)=$ , $000 ; p>$.05] anlamlı fark olduğu bulunmuştur. Gruplar arasındaki farkı ortaya çıkarmak için yapılan Tukey testi sonuçlarına göre tablo 5'te ilk okul, yüksek okul, eğitimi alan gazilerin yüksek okul ve fakülte eğitimi alan gazilere göre depresyon ve anksiyete düzeylerinin daha yüksek olduğu görülmüştür. Bu sonuçlara göre eğitim düzeyleri artıkça depresyon, anksiyete ve stres düzeylerinde azalma olduğu gözlenmektedir.

\section{Tartışma ve Sonuç}

Psikolojik problemlerin ihmal edilmesi ciddi bir realite olarak kabul edilmektedir. Başta çocuk ve ergenler olmak üzere hemen hemen her yaş grubunda depresyon, anksiyete ve stres görülmektedir. Gazilerde savaş sonrası depresyon, anksiyete ve stres düzeylerinin belirlenmesi amacıyla yapılan bu çalışma önemli sonuçlara ulaşılmıştır örneğin; Mesleki durum açısından bireylerin depresyon, anksiyete ve stres düzeylerinin anlamlı fark olduğu görülmüştür. Mesleki durum değişkenine göre katılımcıların depresyon, anksiyete ve stres açısından farklın anlamlı olup olmadığı belirlemek için yapılan tek yönlü varyans (ANOVA) analizi sonucunda depresyon ve anksiyete düzeylerinde anlamlı fark olduğu şeklinde ifade edilmiştir. Alanyazın incelendiğinde, mesleki durum ile depresyon, anksiyete ve stres arasındaki farklıl1klarını doğrudan inceleyen yurt içi ya da yurtdışı herhangi bir çalışmaya rastlanmamıştır. Ancak Kılıç ve İnci (2015), yapmış oldukları araştırmada psikolojik rahatsızlık ile mesleki durum arasında çeşitli türden ilişkiler elde etmiştir. $\mathrm{Bu}$ araştırmaların bazıları stres ve travma belirtilerinin kullanıldığı bulunmuştur. Araştırmanın sonuçlarına genç ve daha eğitimsiz olan çalışanların mesleki travmalar karşısında stresin daha büyük risk altında olduğunu belirtmişlerdir. Son birkaç yıldır mesleğe bağlı psikolojik rahatsızlıklar giderek artmaktadır. İssizliğin giderek artması, zorlaşan yaşam koşulları, monoton iş ortamı, yoğun dikkat gerektiren işler, vardiyalı çalışma, aşırı sorumluluk gibi iş şartları, çalışanlarda ya da işsiz olanlarda ciddi psikolojik rahatsızlıklara neden olabilmektedir. Depresyon, anksiyete ve stres gibi duygu durumları günümüzde yaşamımızın ayrılmaz bir parçasıdır. Giderek işsizliğin artması, zorlaşan yaşam koşulları, hızlı değişimin getirdiği belirsizlikler ve insan ilişkilerinin değişmesi depresyon, anksiyete ve stresi arttıran faktörler olduğu söylenebilir.

Sosyo-Ekonomik durum açısından bireylerin depresyon, anksiyete ve stres düzeylerinin anlamlı fark olduğu görülmüştür. Sosyo-Ekonomik durum değişkenine göre katılımcıların depresyon, anksiyete ve stres açısından farkın anlamlı olup olmadığı belirlemek için yapılan tek yönlü varyans analizi sonucunda depresyon, anksiyete ve stres düzeylerinde anlamlı fark olduğu saptanmıştır. Alanyazın incelendiğinde, sosyo-ekonomik durum ile depresyon, anksiyete ve stres arasındaki farklılıklarını doğrudan inceleyen araştırmaya rastlanmamıştır. Ancak bu ilişki konusunda fikir sahibi olabilecek dolaylı araştırmalar mevcuttur. Karakaya ve diğerleri yaptıkları araştırmada TSSB belirtilerinin şiddetini etkileyen etkenler olduğunu ortaya koymuşlardır (Karakaya ve diğ, 2004), yapılan bir başka çalışmada olası TSSB ve depresyon düzeylerinin yüksek çıktığını belirtmişlerdir (Kılıç ve Ulusoy, 2003), bir derleme çalışmasında, 
(Brewin, Andrews ve Valentine, 1999) yaptıkları araştırmada 14 tane faktörün TSSB'yi yordadığı yönünde bir sonuca ulaştıklarını rapor etmektedirler. Bu 14 faktör, cinsiyet (kadın olmak), travmatik yaşantı sırasında yaşın küçük olması, düşük sosyo-ekonomik statü, düşük eğitim düzeyi, düşük zekâ düzeyi, azınlık statüsü, psikolojik bozukluk tarihçesi, çocuklukta istismar, daha önce geçirilen travmatik yaşantı öyküsü, zor çocukluk koşulları, ailede psikolojik bozukluk öyküsü, travmatik yaşantının şiddeti, travmatik yaşantı sonrasında sosyal destek yoksunluğu, travmatik yaşantı sonrasında genel yaşam stresi olarak belirtilmektedir. Araştırmaların birçoğunda anlamlı bir fark olduğunu söyleyebiliriz. Araştırmacılara göre erkek olmak, çocuklukta davranım bozukluğuna sahip olmak, ailede psikolojik bozukluk öyküsünün olması, daha önce travmatik yaşantıya maruz kalmak, majör depresyon öyküsünün olması, şehirde yaşamak ve düşük eğitim düzeyinde sahip olmak, azınlık mensubu olmak, düşük sosyo-ekonomik düzeyi gibi faktörlerin travma sonrası stresin yordadığı yönünde bir sonuca ulaştıklarını rapor etmişlerdir.

Sosyo-ekonomik bakımda yoksunluk içinde olan bireylerin toplumda kabul gören yollardan gereksinimlerini karşılayamamaları ve bu yolla toplumda bir statü elde edemeyecek olmaları nedeniyle kişilerde depresyon, anksiyete ve stres gibi psikolojik durumların ortaya çıkması kaçınılmazdır.

Eğitim durum açısından bireylerin depresyon, anksiyete ve stres düzeylerinin anlamlı fark olduğu görülmüsstür. Eğitim durum değişkenine göre katılımcıların depresyon, anksiyete ve stres açısından farkın anlamlı olup olmadığı belirlemek için yapılan tek yönlü varyans analizi ve $t$-test $i$ sonucunda depresyon, anksiyete ve stres düzeylerinde anlamlı fark olduğu bulunmuştur. Alanyazın incelendiğinde, eğitim durum ile depresyon, anksiyete ve stres arasındaki farklılıklarını doğrudan inceleyen araştırmaya rastlanmamıştır. Eğitim düzeyi açısından bireylerde depresyon ve anksiyete değerlerinin daha yüksek olduğu sonucuna varmışlardır (Tarsuslu ve diğ, 2010), elde etikleri bulgulara göre Travma sonrası stres bozukluğu ile eğitim düzeyi yönünden farklılık olmadığ1 bulgusuna varmışlardır (Mehdiyev ve diğ, 2009), Samanc1 ve Ekici' göre ise eğitim seviyesinin düşüldüğü ve yetersiz sosyal destek de TSSB oluşmasındaki kolaylaştırıcı faktörler olduğunu belirtmişlerdir (Samancı ve Ekici, 1998). Araştırmaların birçoğunda fark olduğu bulunmuştur sadece bir araştırmada anlamlı bir farkın olmadığı saptanmıştır. Eğitim insanın doğumundan ölümüne kadar geçen süreçtir. Eğitim sürecinde kendi yaşantıları esastır. İnsan davranışında, kendi yaşantısı yoluyla ve bilinçli olarak istenilen yönde değişme meydana getirme sürecidir. Yani kişinin tutum ve diğer davranış biçimlerini geliştirdiği süreçtir. Kosova gazilerinin depresyon, anksiyete ve stres konusunda Türkiye'de yapılan ilk araştırmadır.

Son olarak bu araştırmanın, gazilerin depresyon, anksiyete ve stres düzeyleri arasındaki ilişkilere yönelik somut bulgular ve önemli kanitlar ortaya koyduğu söylenebilir. Bu açıdan çalışmanın psikolojik danışmanlık alanında önemli bir boşluğu dolduracağına inanılmaktadır.

\section{Kaynaklar}

Aker, A. T., Sorgun, E., Mestçioğlu, Ö., Karakaya, I., Kalender, D., Acar, G., ... ve Acicbe, Ö. (2008). İstanbul'daki bombalama eylemlerinin erişkin ve ergenlerdeki travmatik stres etkileri. Türk Psikoloji Dergisi, 23(61), 63-71.

Brewin, C. R., Andrews, B., Rose, S., and Kirk, M. (1999). Acute Stress Disorder and Posttraumatic Stress Disorder in Victims of Violent Crime. American Journal of Psychiatry, 156, 360-366.

Büşra, B. (2014). Deprem Travmasının Kronik Psikolojik Etkileri: Düzce Depremi'nden 14 Yll Sonra Travma Sonrasl Stres ve Depresyon Belirtilerinin Yayginlığ Faktörleri. Yayınlanmamış Yüksek Lisans Tezi. Haliç Üniversitesi. Sosyal Bilimler Enstitüsü.

Davidson , J., Schwartz, M., Storck, M., vd. (1985). A Diagnostic and Family Study of Posttraumatic Stress Disorder. Am J Psychiatry, 142, 90-93.

Dekel, R., Solomon, Z., Elklit, A. ve Ginzburg, K. (2004). World Assumptions and Combat-Related Posttraumatic Stress Disorder. The Journal of Social Psychology, 144, 407-420.

Duran, Ş. ve Ünsal, G. (2014). Çankırı İlindeki Şehit Aileleri ve Malul Gazilerin Psikolojik Dayanıklılık ve Depresif Durumlarının Belirlenmesi. Acıbadem Üniversitesi Sağllk Bilimleri Dergisi, 5(2), 158-162.

Eşsizoğlu, A., Yaşan, A., Bülbül, İ., ve diğ. (2009). Bir Terör Saldırı Sonrasında Travma Sonrası Stres Bozulduğu Gelişimini Etkileyen Risk Faktörleri. Türk Psikiyatri Dergisi, 20, 118-126.

Güloğlu, B. ve Kararrmak, Ö. (2013). Posttraumatic Stress Disorder Among Turkish Veterans of the Southeast: Anadolu Psikiyatri Dergisi, 14(3), 237-244.
Haskell, S. G., Gordon, K. S., Mattocks, K., Duggal, M., Erdos, J., Justice, A. ve Brandt, C. A. (2010). Gender differences in rates of depression, PTSD, pain, obesity, and military sexual trauma among Connecticut war veterans of Iraq and Afghanistan. Journal of Women's Health, 19(2), 267-271.

Karakaya, I., Ağaoğlu, B., Çoşkun, A. ve Şişmanlar, Ş. G. (2004). Marmara Depreminden Ự Buçuk Yıl Sonra Ergenlerde TSSB, Depresyon ve Anksiyete Belirtileri. Türk Psikiyatri Dergisi, 15(4), 257-266.

Karasar, N. (1984). Bilimsel Araşttrma Metodu: Ankara: Hacetepe Taş Kitapçılık.

Kaya, B. (2000). Travma Sonrası Stres Bozukluğunda Komorbidite. Psikiyatri Dünyasl, 4, 37-43.

Kılıç, C. ve İnci, F. (2015). Acil Tıp Çalışanlarında Travmatik Stres: Yaş ve Eğitimin Koruyucu Etkisi. Türk Psikiyatri Dergisi, 26(4), 236-241.

Kılıç, C. ve Ulusoy, M. (2003). Psychological Effects of the November 1999 Earthquake in Turkey: An Epidemiological Study. Acta Psychiatrica Scandinavica, 108(3), 232-238.

Lovibond, S. H. ve Lovibond, P. F. (1995). Manual for the Depression Anxiety Stress Scale. Sydney: The Psychological Foundation of Australia, Inc.

McInnes, K., Sarajlić, N., Lavelle, J. ve Sarajlić, I. (1999). Disability associated with psychiatric comorbidity and health status in Bosnian refugees living in Croatia. Jama, 282(5), 433439.

Mehdiyev, E. S., Çelik, C., ve Özdemir, B. (2009). Karabağ Savaşı Örnekleminde Travma Sonrası Stres Bozukluğu ve Alkol Kullanım Bozuklukları Birlikteliği. Gülhane Tip Dergisi, 51, 212-215. 
O'Brien, L. S. ve Hughes, S. J. (1991). Symptoms of Posttraumatic Stress Disorder in Falkland Veterans Five Years After the Conflict. Br J Psychiatry, 159, 135-141.

Özgen, F. ve Aydın, H. (1991). Travma Sonrası Stres Bozukluğu; Klinik Psikiyatri Dergisi, 1, 34-41.

Pynoos, R. S., Frederick, C., Nader, K., vd. (1987) Life Threat Andposttraumatic Stress in School-Age Children. Arch Gen Psychiatry, 44, 1057-1063.

Samancı, A.Y. ve Ekici, G. (1996). Savaş Afet, İskence, Tecavüz ve Posttravmatik Stres Bozukluğu. Düşünen Adam, 11(1), 19-26.
Shalev, A.Y. ve Freedman, S. (2005). PTSD Following Terrorist Attacks: A Prospective Evaluation. ,Am J Psychiatry, 162, 1188- 1191.

Shannon, M. P., Lonigan, C. J., Finch Jr, A. J. ve Taylor, C. M. (1994). Children exposed to disaster: I. Epidemiology of posttraumatic symptoms and symptom profiles. Journal of the American Academy of Child \& Adolescent Psychiatry, 33(1), 80-93.

Tarsuslu, T., Yümin, E. T., Öztürk, A. ve Yümin, M. (2010). Kronik fiziksel özürlü bireylerde ağrn, depresyon, anksiyete ve fonksiyonel bağımsızlık ile yaşam kalitesi arasındaki ilişki. A ̆grl, 22(1), 30-36. 